Check for updates

Cite this: RSC Adv., 2019, 9, 19278

\title{
Research progress of photocatalytic sterilization over semiconductors
}

\author{
Mingfu Gong, (D) ab Shilin Xiao, ${ }^{a}$ Xian Yu, ${ }^{a}$ Chencheng Dong, ${ }^{b}$ Jiahui Ji, ${ }^{b}$ Dong Zhang ${ }^{\star a}$ \\ and Mingyang Xing $\mathbb{D}$ *b
}

Considering the situation that environmental issues become more serious day by day, research on practical applications of semiconductor photocatalysis for environmental purification has attracted broad attention, including the remediation of water pollution, air contaminant treatment, photocatalytic sterilization etc., among which the application of semiconductor photocatalytic properties for the disinfection of soil surfaces, air and water, such as $\mathrm{TiO}_{2}$, is of great interest. In this paper, we give an overview of the photocatalytic antibacterial ability of $\mathrm{TiO}_{2}$ and other novel carbon material semiconductors. We have introduced the background information of photocatalytic disinfection and the disinfection mechanism of pure $\mathrm{TiO}_{2}$. Furthermore, other modified $\mathrm{TiO}_{2}$ sterilization materials are listed, such as those with doping modification. In addition, some novel carbon based nanomaterials are discussed as well in this review, for instance, $\mathrm{g}-\mathrm{C}_{3} \mathrm{~N}_{4}$, carbon nanotubes and graphene nanosheets. Finally, we present an outlook over two dimensional (2D) materials and coupling techniques based on the combination of photocatalysis and other sterilization technologies.

Received 11th March 2019 Accepted 12th May 2019

DOI: 10.1039/c9ra01826c

rsc.li/rsc-advances acid macromolecules, which causes extensive damage to biological cell structures either directly or through a series of oxidative chain destructions. ${ }^{4}$ Moreover, some other nanomaterials, such as $\mathrm{ZnO}, \mathrm{CdS}, \mathrm{CeO}_{2}$ and $\mathrm{BiVO}_{4}$ etc., show excellent performance in photocatalytic sterilization., ${ }^{2,5-9} \mathrm{TiO}_{2}$ has always been considered as the most promising catalyst in the photocatalytic disinfection of bacteria; however, due to the wide band gap of anatase $\mathrm{TiO}_{2}$ ( 3.2 vs. $3.0 \mathrm{eV}$ of rutile), it is limited to UV light at wavelengths less than $385 \mathrm{~nm}$, which accounts for less than 5\% of solar energy. ${ }^{\mathbf{1 0 , 1 1}}$ Thus, it is indeed of great necessity to expand its adsorption region from UV light to the visible light region. Some modification has been well done on $\mathrm{TiO}_{2}$, for instance non-metal and metal doping or construction of heterojunction semiconductors. Another effective strategy is to develop novel candidate nanomaterials for photocatalytic disinfection. Carbon materials, represented by $\mathrm{g}-\mathrm{C}_{3} \mathrm{~N}_{4}$, carbon nanotubes (CNTs) and graphene oxide (GO) have been deeply investigated in photocatalysis. Hence, in this review, we have not only reviewed the representative $\mathrm{TiO}_{2}$ nanomaterials, but also emphasized the brand new carbon nanomaterials of $\mathrm{g}-\mathrm{C}_{3} \mathrm{~N}_{4}$, carbon nanotubes (CNTs) and graphene oxide (GO) for disinfection applications. To this end, we propose the future research direction in photocatalytic sterilization over semiconductors.

\section{Photocatalytic disinfection of $\mathrm{TiO}_{2}$}

\subsection{Photocatalytic disinfection of pure $\mathrm{TiO}_{2}$}

Heterogeneous photocatalytic oxidation technology has always been a hot spot at home and abroad. ${ }^{12-14}$ Since 1972, Fujishima 
and Honda ${ }^{15}$ reported that the redox reaction of light-emitting $\mathrm{TiO}_{2}$ could sustainably take place in photovoltaic cells. After that, in 1976, Carey et al. ${ }^{\mathbf{1 6}}$ successfully applied the $\mathrm{TiO}_{2}$ photocatalytic oxidation method to dechlorination and detoxification of PCB compounds in water. In 1985, Tadashi Matsunaga et $a .^{17}$ firstly found that $\mathrm{TiO}_{2}$ had a bactericidal effect under ultraviolet light. The experimental results showed that with the loading of $\mathrm{TiO}_{2}$ nanoparticles, co-cultured Lactobacillus acidophilus, yeast, and Escherichia coli could be completely killed under the irradiation of a halide lamp for 60-120 min. Their findings opened a new era in the field of sterilization, thus resulting in attempts to use this novel photocatalytic technology for disinfecting drinking water and removing bioaerosols from indoor air environments. In 1993, Ireland et al. ${ }^{18}$ found that titanium dioxide in the anatase phase could be used as a photocatalyst to generate hydroxyl radicals in a Flow-Through water reactor as shown in Fig. 1.

In 1994, Wei et al. ${ }^{19}$ found that the irradiation of suspensions containing Escherichia coli ( 106 cells per $\mathrm{mL}$ ) and $\mathrm{TiO}_{2}$ (anatase) under UV-visible light with a wavelength longer than $380 \mathrm{~nm}$ resulted in the killing of the bacteria within minutes. Apart from Escherichia coli, Giardia lamblia is another target in photocatalytic sterilization. In 2004 , Lee et al. ${ }^{20}$ utilized a $\mathrm{TiO}_{2}$ colloidal solution to sterilize the Giardia lamblia. To be more specific, the $\mathrm{TiO}_{2}$ solution was made into films using a modified hydrothermal method, and directly coated on a UV-lamp. As a result, the $\mathrm{TiO}_{2}$ films were transparent until 5-times coating. In 2015, Wang et al. ${ }^{21}$ reported visible-light-sensitive sub-5 nm $\mathrm{TiO}_{2}$ nanoparticles, which were applied in the degradation of organic pollutants in water and air, and the bacterial disinfection field. Those sub-5 nm $\mathrm{TiO}_{2}$ nanoparticles were fabricated without any doping or calcination treatments, maintaining abundant hydroxyls on the surfaces and subsurface, which indicated a high ratio of surface to bulk defects. Fig. 2(a) shows a lattice space of $\sim 0.36 \mathrm{~nm}$, which is indexed to the $\{101\}$ facets of anatase $\mathrm{TiO}_{2}$. The gel (1.0 wt\%) shows a high efficiency for visible-light-driven photocatalytic dye degradation (Fig. 2(c)). Significantly, the $\mathrm{TiO}_{2}$ gel also shows impressive durability, with almost no loss of visible-light activity after 5 runs. Finally, qualitative (Fig. 2(b)) antibacterial evaluations are considered for $\mathrm{TiO}_{2}$ gel. It can effectively sterilize bacteria SA under visible light.

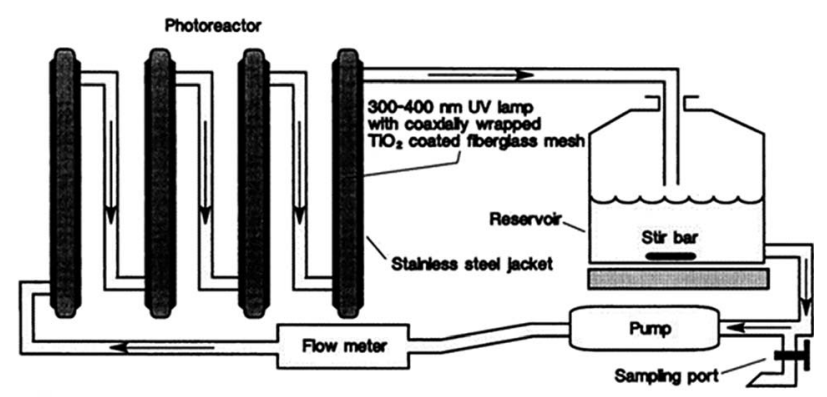

Fig. 1 Schematic diagram of the experimental $\mathrm{TiO}_{2}$ photoreactor showing the flow configuration (this figure has been reproduced from ref. 18 with permission from Elsevier). (a)

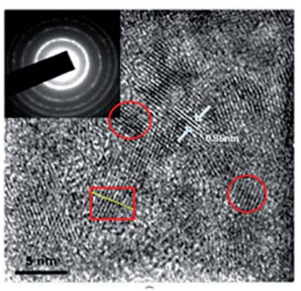

(b)

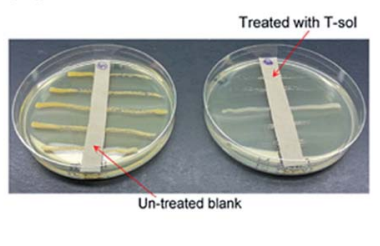

(c)

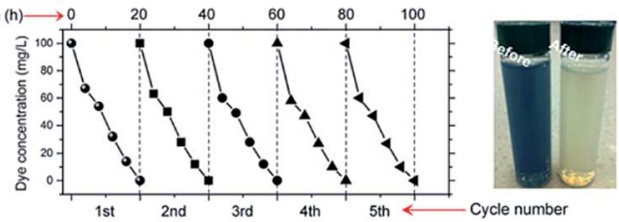

Fig. 2 (a) HRTEM image of T-sol. (b) Visible-light-driven photocatalytic sterilization of bacteria SA through qualitative. (c) Recyclability tests of T-sol for total 5 runs of the dye degradation under visible light (this figure has been adapted from ref. 21 with permission from Royal Society of Chemistry).

\subsection{The mechanism of the antibacterial properties of $\mathrm{TiO}_{2}$}

Advanced Oxidation Processes (AOPs) involving $\mathrm{TiO}_{2}$-mediated photocatalysis technology have attracted considerable attention from scientists. Among them, the photocatalytic oxidation process is mainly started by photogenerated electrons and holes through the irradiation of a semiconductor (e.g., such as $\mathrm{TiO}_{2}$ ) via sunlight. When irradiated by light, the electrons $\left(\mathrm{e}^{-}\right)$are excited into the conduction band (CB), thus leaving a hole $\left(\mathrm{h}^{+}\right)$ in the valence band (VB) of the photocatalyst. Then, these charge carriers $\left(\mathrm{e}^{-} / \mathrm{h}^{+}\right.$pair) migrate to the surface/interface of the photocatalyst and participate in the redox reactions. The whole mechanism is illustrated in eqn (1)-(8) as follows, involving reactive oxygen species (ROS) species such as $\mathrm{HO}^{\circ}$, $\mathrm{O}_{2}{ }^{-}, \mathrm{HO}_{2}{ }^{\circ}$, etc. It is recognized that hydroxyl radicals are primarily responsible for this disinfection property, especially against bacteria. $^{22}$

$$
\begin{gathered}
\mathrm{TiO}_{2}+h v \rightarrow \mathrm{TiO}_{2}\left(\mathrm{e}_{\mathrm{CB}}^{-}+\mathrm{h}_{\mathrm{VB}}^{+}\right) \\
\mathrm{TiO}_{2}\left(\mathrm{~h}_{\mathrm{VB}}^{+}\right)+\mathrm{H}_{2} \mathrm{O}_{\mathrm{ad}} \rightarrow \mathrm{TiO}_{2}+{ }^{\cdot} \mathrm{OH}_{\mathrm{ad}}+\mathrm{H} \\
\mathrm{TiO}_{2}\left(\mathrm{~h}_{\mathrm{VB}}^{+}\right)+{ }^{-} \mathrm{OH}_{\mathrm{ad}} \rightarrow \mathrm{TiO}_{2}+\cdot \mathrm{OH} \\
\mathrm{TiO}_{2}\left(\mathrm{e}_{\mathrm{CB}}^{-}\right)+\mathrm{O}_{2} \rightarrow \mathrm{TiO}_{2}+\mathrm{O}_{2}^{\cdot-} \\
\mathrm{O}_{2}^{\cdot-}+\mathrm{H}^{+} \rightarrow \mathrm{HO}_{2}^{\cdot} \\
\mathrm{O}_{2}^{\cdot-}+\mathrm{HO}_{2}^{\cdot} \rightarrow{ }^{\cdot} \mathrm{OH}+\mathrm{O}_{2}+\mathrm{H}_{2} \mathrm{O}_{2} \\
2 \mathrm{HO}_{2} \cdot \rightarrow \mathrm{O}_{2}+\mathrm{H}_{2} \mathrm{O}_{2} \\
\mathrm{TiO}_{2}\left(\mathrm{e}_{\mathrm{CB}}^{-}\right)+\mathrm{H}_{2} \mathrm{O}_{2} \rightarrow \mathrm{TiO}_{2}+{ }^{-} \mathrm{OH}+{ }^{\cdot} \mathrm{OH}
\end{gathered}
$$

Furthermore, other ROS species (such as singlet oxygen and hydrogen peroxide) also play a pivotal role in the sterilization, as they can actively participate in the oxidation of cellular components, membrane leakage of the microbial cell wall, and other processes. ${ }^{23}$ As shown in Fig. 3, the full mechanism was 


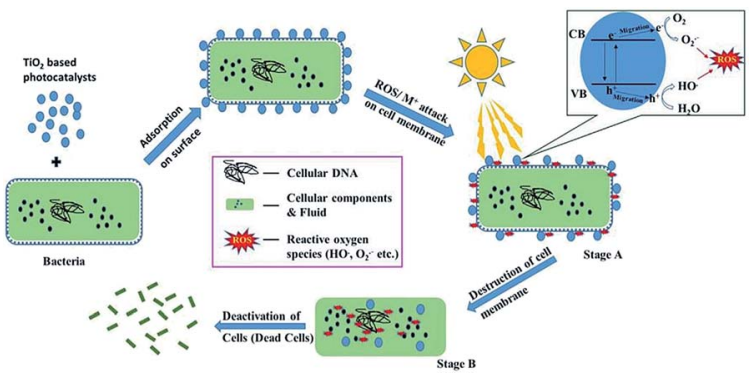

Fig. 3 The mechanism of the photocatalytic disinfection of bacteria (this figure has been reproduced from ref. 23 with permission from Elsevier).

clearly exhibited. Other various types of metal oxide and metal modified $\mathrm{TiO}_{2}$ were also displayed, such as the following example consisting of $\mathrm{Ag}^{+}$as the $\mathrm{M}^{n+}$ species. ${ }^{23}$ Firstly, $\mathrm{TiO}_{2}$ based photocatalysts were mixed with bacteria, and then could be adsorbed onto the surface of cell membranes. After irradiation by sunlight, the ROS $/ \mathrm{M}^{n+}$ would start to attack cells, the cell membranes were destroyed and were finally deactivated. ${ }^{22}$

\subsection{Photocatalytic disinfection of modified $\mathrm{TiO}_{2}$ materials}

In addition to the application of pure $\mathrm{TiO}_{2}$ nanoparticles in sterilization, other modified $\mathrm{TiO}_{2}$ materials and $\mathrm{TiO}_{2}$ nanocomposites have been extensively investigated. Trapalis et al. ${ }^{24}$ studied the bactericidal activity against Escherichia coli of $\mathrm{Fe}^{3+}$ doped $\mathrm{TiO}_{2}$ thin films on glass substrate. Sayllkan et al. ${ }^{25}$ prepared $\mathrm{Sn}^{4+}$ doped $\mathrm{TiO}_{2}\left(\mathrm{TiO}_{2}-\mathrm{Sn}^{4+}\right)$ particulates by a hydrothermal process. $\mathrm{TiO}_{2}-\mathrm{Sn}^{4+}$ was coated onto glass surfaces to investigate the photocatalytic antibacterial effect of $\mathrm{Sn}^{4+}$ doping to $\mathrm{TiO}_{2}$ against Gram negative Escherichia coli (E. coli) and Gram positive Staphylococcus aureus (S. aureus). Fig. 4(a) elaborately shows the preparation steps of $\mathrm{TiO}_{2}-\mathrm{Sn}^{4+}$ particulates. Prior to preparing the coating solution, $\mathrm{TiO}_{2}-\mathrm{Sn}^{4+}$ sols composed of a large number of $\mathrm{TiO}_{2}-\mathrm{Sn}^{4+}$ particulates were prepared by dispersing the particles into deionized water in the absence of dispersant. Then the mixture was merely treated in an ultrasonic bath for a few minutes, thus the transparent $\mathrm{TiO}_{2}-\mathrm{Sn}^{4+}$ sols were obtained. The bacterial test results for Escherichia coli
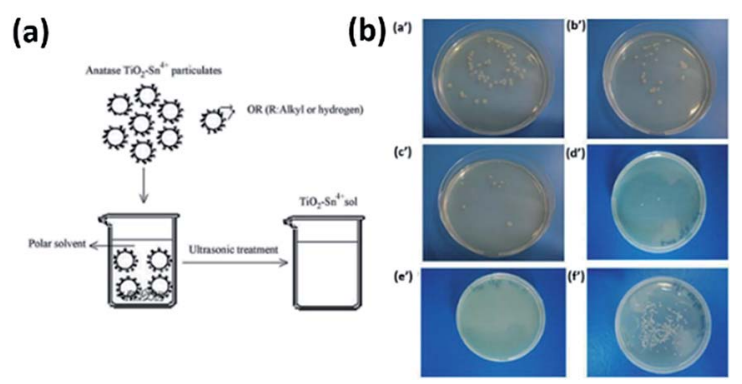

Fig. 4 (a) Preparation steps of transparent $\mathrm{TiO}_{2}-\mathrm{Sn}^{4+}$ sol in polar solvent system. (b) Photo images for the results of $E$. coli test with the coated surfaces containing $\left(a^{\prime}\right) 10,\left(b^{\prime}\right) 20,\left(c^{\prime}\right) 30,\left(d^{\prime}\right) 40$ and $\left(e^{\prime}\right) 50 \%$ $\mathrm{TiO}_{2}-\mathrm{Sn}^{4+}$, and (f) uncoated surface (this figure has been reproduced from ref. 25 with permission from Elsevier). are shown in Fig. 4(b). It could be clearly seen that $50 \%(\mathrm{w} / \mathrm{w})$ $\mathrm{TiO}_{2}-\mathrm{Sn}^{4+}$ exhibited the optimal antibacterial effect.

Furthermore, Wu et al. ${ }^{26}$ synthesized a photocatalyst called $\mathrm{PdO} / \mathrm{TiON}$ composed of palladium oxide and nitrogen-doped titanium oxide using a sol-gel process. Moreover, the photocatalytic activity of the PdO/TiON catalyst was investigated by using different bacterial indicators, including Gram-negative cells of Escherichia coli and Pseudomonas aeruginosa, and Gram-positive cells of Staphylococcus aureus. In 2010, Karunakaran et al. ${ }^{27}$ reported the highly efficient photocatalytic disinfection of bacteria using $\mathrm{Cu}$-doped $\mathrm{TiO}_{2}$ under visible light for the first time. Additionally, a $\mathrm{TiO}_{2}-\mathrm{NiFe}_{2} \mathrm{O}_{4}$ photocatalyst was synthesized by Misra. ${ }^{28}$ In this work, the reverse micelle and chemical hydrolysis techniques had been successfully combined to synthesize composite nanoparticles consisting of a photocatalytic shell of titania and a magnetic core of nickel ferrite. Fig. 5(a) shows the TEM and HRTEM images of anatase and brookite titania-coated $\mathrm{NiFe}_{2} \mathrm{O}_{4}$ nanoparticles. Fig. 5(b) presents the degradation efficiency of methyl orange under UV light.

Misra and his co-workers ${ }^{29}$ introduced $\mathrm{Nd}^{3+}$ dopant into the $\mathrm{TiO}_{2}$ shell of titania-coated nickel ferrite composite nanoparticles. As a result, the as-prepared catalyst could significantly enhance the photocatalytic degradation of methyl orange and the anti-microbial performance, which was attributed to the restriction of electron-hole recombination and the decrease of the titania band gap energy. Moreover, the retention of magnetic strength ensured that the movement of the composite nanoparticles could be controlled by a magnetic field, facilitating their application as removable anti-microbial photocatalyst nanoparticles. Fig. 6(a) shows the HRTEM image of the $\mathrm{TiO}_{2}-\mathrm{NiFe}_{2} \mathrm{O}_{4}$ composite. The $\mathrm{NiFe}_{2} \mathrm{O}_{4}$ magnetic core is 4-6 nm and the $\mathrm{TiO}_{2}$ shell is $2-3 \mathrm{~nm}$, whereas the HRTEM image of $\mathrm{Nd}^{3+}$-doped $\mathrm{TiO}_{2}$-coated $\mathrm{NiFe}_{2} \mathrm{O}_{4}$ nanoparticles is shown in Fig. 6(c). The $\mathrm{NiFe}_{2} \mathrm{O}_{4}$ magnetic core is $8-10 \mathrm{~nm}$ and the $\mathrm{TiO}_{2}$ shell is $2-3 \mathrm{~nm}$. The specific degradation performance of methyl (a)

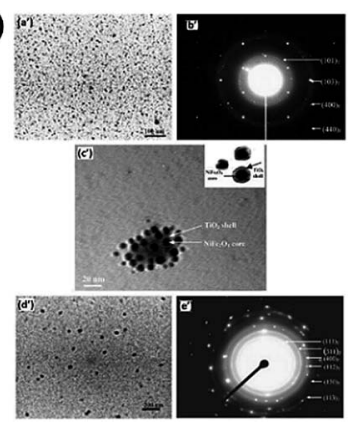

(b)

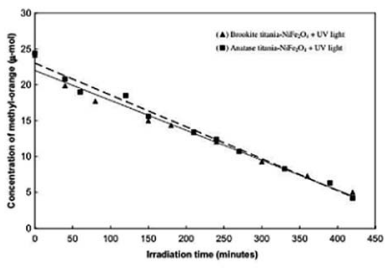

Fig. 5 (a) TEM images $\left(a^{\prime}\right)$ of and $\left(b^{\prime}\right)$ electron diffraction pattern for anatase titania-coated $\mathrm{NiFe}_{2} \mathrm{O}_{4},\left(c^{\prime}\right)$ HRTEM image of core-shell structure for anatase titania-coated $\mathrm{NiFe}_{2} \mathrm{O}_{4}$ nanoparticles, $\left(d^{\prime}\right)$ TEM image and $\left(e^{\prime}\right)$ the corresponding electron diffraction for brookite titania-coated $\mathrm{NiFe}_{2} \mathrm{O}_{4}$. (b) Concentration of methyl-orange versus irradiation time in the presence of anatase- and brookite- $\mathrm{TiO}_{2}$-coated $\mathrm{NiFe}_{2} \mathrm{O}_{4}$ nanoparticles (this figure has been reproduced from ref. 28 with permission from Elsevier). 
(a)

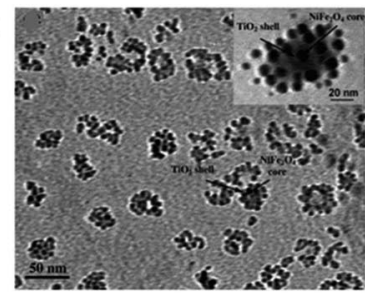

(c)

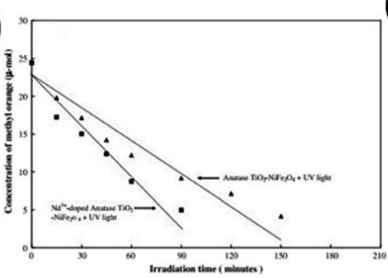

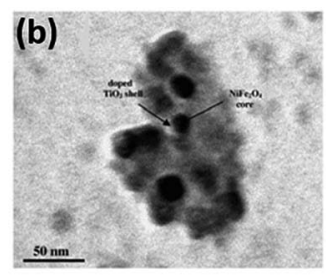

(d)

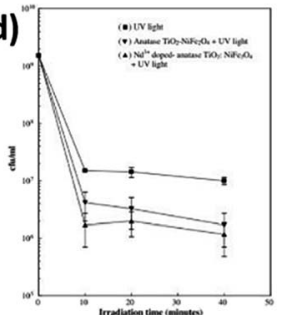

Fig. 6 (a) HRTEM image of core-shell structure for undoped $\mathrm{TiO}_{2}-$ $\mathrm{NiFe}_{2} \mathrm{O}_{4}$ composite nanoparticles, illustrating the core-shell structure in the inset. (b) Concentration of methyl-orange versus irradiation time in the presence of undoped $\mathrm{TiO}_{2}$-coated $\mathrm{NiFe}_{2} \mathrm{O}_{4}$ nanoparticles and $\mathrm{Nd}^{3+}$-doped $\mathrm{TiO}_{2}$-coated $\mathrm{NiFe}_{2} \mathrm{O}_{4}$ nanoparticles. (c) HRTEM image of core-shell structure for $\mathrm{Nd}^{3+}$-doped $\mathrm{TiO}_{2}: \mathrm{NiFe}_{2} \mathrm{O}_{4}$ composite nanoparticles. (d) $E$. coli bacterial inactivation response of $\mathrm{Nd}^{3+}$-doped $\mathrm{TiO}_{2}$-coated $\mathrm{NiFe}_{2} \mathrm{O}_{4}$ nanoparticles and undoped $\mathrm{TiO}_{2}$-coated $\mathrm{NiFe}_{2} \mathrm{O}_{4}$ nanoparticles as a function of irradiation time (this figure has been reproduced from ref. 29 with permission from Elsevier).

orange and $E$. coli bacterial inactivation activity are exhibited in Fig. 6(b) and (d).

Similarly, Nardi et al. ${ }^{30}$ investigated functionally graded epoxy composites with various concentration profiles of $\mathrm{Fe}_{3}$ $\mathrm{O}_{4} @ \mathrm{TiO}_{2}$ core-shell nanoparticles (NPs), and focused on their antibacterial properties. It was revealed that the composite surfaces showed effective antibacterial performance but were inactivated in a few hours, which was attributed to the suitable amount of NPs and their anisotropic distribution in the subsurface layers facing the bacteria.

In the above section, we have reviewed the disinfection ability of pure $\mathrm{TiO}_{2}$ and modified $\mathrm{TiO}_{2}$ nanomaterials, accompanied by the disinfection mechanism. It is well known that hydroxyl radicals are primarily responsible for this disinfection property. Besides, other reactive oxygen species (ROS, such as singlet oxygen and hydrogen peroxide) also play a pivotal role in sterilization. What's more, on one hand, one of the obstacles in employing $\mathrm{TiO}_{2}$ nanomaterials for industrial use is the recycling problem due to the small particle size. On the other hand, the light utilization efficiency of $\mathrm{TiO}_{2}$ was mainly restricted to the UV region, which restrains the application in practical photocatalytic disinfection of contaminated water. Thus, to some extent, the modification of $\mathrm{TiO}_{2}$ nanomaterials, such as nonmetal and metal doping, compounded with other semiconductors, is beneficial for fully utilizing solar light.

\section{Photocatalytic sterilization of carbon materials}

Apart from the conventional photocatalysts of metal oxide semiconductors, carbon based semiconductors, such as g- $\mathrm{C}_{3} \mathrm{~N}_{4}$,

have been well considered to be highly efficient visible-lightdriven photocatalysts in recent years. $\mathrm{g}^{-} \mathrm{C}_{3} \mathrm{~N}_{4}$ is a semiconductor material with a narrow band gap and is equipped with visible light response, which can increase the separation efficiency of photogenerated electron-hole pairs. ${ }^{31}$ Thus, g- $\mathrm{C}_{3} \mathrm{~N}_{4}$ has been used to modify $\mathrm{TiO}_{2}$ for improving its photocatalytic performance. For instance, Tian et al..$^{32}$ prepared $\mathrm{g}-\mathrm{C}_{3} \mathrm{~N}_{4} / \mathrm{TiO}_{2}$ composite photocatalysts, which were applied to enhance the sterilization performance of fluorocarbon resin (PEVE) coatings. The $\mathrm{g}-\mathrm{C}_{3} \mathrm{~N}_{4}$ was prepared using melamine thermolysis as shown in Fig. 7. The antibacterial activity of coatings under UV and visible light were also investigated. The sterilization performance of the PEVE composite coatings was enhanced by the addition of $\mathrm{TiO}_{2}$ and $\mathrm{g}-\mathrm{C}_{3} \mathrm{~N}_{4} / \mathrm{TiO}_{2}$ under UV and visible-light irradiation.

What's more, in 2016, $\mathrm{Bi}_{2} \mathrm{MoO}_{6} / \mathrm{g}-\mathrm{C}_{3} \mathrm{~N}_{4}$ heterojunctions were fabricated using an in situ solvothermal method via using $\mathrm{g}$ $\mathrm{C}_{3} \mathrm{~N}_{4}$ nanosheets as precursors by Li et al. ${ }^{33}$ The photocatalytic activities were tested with hydrogen evolution from water splitting and disinfection of bacteria under visible light irradiation. The results indicated that exfoliating bulk $\mathrm{g}-\mathrm{C}_{3} \mathrm{~N}_{4}$ to $\mathrm{g}$ $\mathrm{C}_{3} \mathrm{~N}_{4}$ nanosheets greatly enlarged the specific surface area and shortened the diffusion distance for photogenerated charges, which could not only promote the photocatalytic performance but also benefit the sufficient interaction with $\mathrm{Bi}_{2} \mathrm{MoO}_{6}$, as shown in Fig. 8 . The $20 \%-\mathrm{BM} / \mathrm{CNN}$ heterojunction exhibited the optimal photocatalytic hydrogen evolution as well as photocatalytic disinfection of bacteria. This work extended the scope of g- $\mathrm{C}_{3} \mathrm{~N}_{4}$-based photocatalysts to the growing demand of clean new energy and drinking water.

Zhu's group prepared a porous g- $\mathrm{C}_{3} \mathrm{~N}_{4}$ nanosheet (PCNS) photocatalyst with a thickness of $2.0 \mathrm{~nm}$ using a simple two-step template-free approach without the addition of extra reagents. ${ }^{34}$ In comparison with the bulk g- $\mathrm{C}_{3} \mathrm{~N}_{4}(\mathrm{BCN})$, PCNSs possess more surface reactive sites, which obviously improve the charge transfer efficiency, and thereby accelerates the separation of photogenerated electron-hole pairs. As a result, the visiblelight-driven photocatalytic disinfection performance of the PCNSs was significantly enhanced. Escherichia coli (E. coli) cells

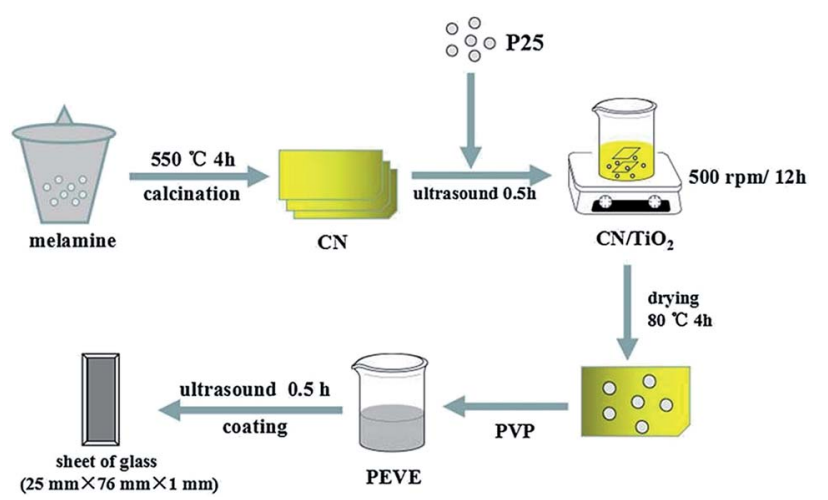

Fig. 7 The preparation progress of CNTP coatings (this figure has been reproduced from ref. 31 with permission from American Chemical Society). 


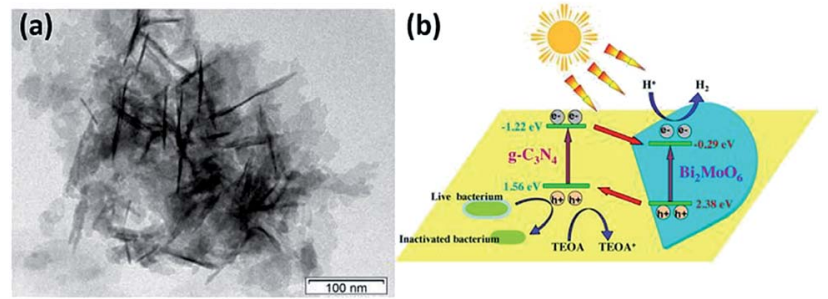

Fig. 8 TEM image (a) and schematic diagram (b) of the photocatalytic mechanism of the $\mathrm{Bi}_{2} \mathrm{MoO}_{6} / \mathrm{g}-\mathrm{C}_{3} \mathrm{~N}_{4}$ composite (this figure has been reproduced from ref. 33 with permission from Elsevier).

could be killed completely by PCNSs within $4 \mathrm{~h}$, whereas only $77.1 \%$ of them could be killed by BCN. Fig. 9 clearly illustrates the disinfection of porous $\mathrm{g}-\mathrm{C}_{3} \mathrm{~N}_{4}$ nanosheets (PCNS) and the TEM images of $E$. coli cells after disinfection for 4 h by using PCNS.

Besides $\mathrm{g}-\mathrm{C}_{3} \mathrm{~N}_{4}$, other carbon based antibacterial nanomaterials, including carbon nanotubes (CNTs) and graphene oxide (GO), are always renewable, easier to obtain and cheaper than silver materials and metal oxides. ${ }^{35}$ CNTs are the type of carbon nanomaterials with a hollow structure and large surface area. However, CNTs have been found to be cytotoxic recently. ${ }^{36,37}$ Fortunately, graphene, another type of carbon nanomaterial, and its derivatives have high antibacterial activity due to physical damage that occurs upon direct contact of bacterial membranes with sharp edges of the graphene sheets; however, the improved oxidative stress induced by graphenebased materials can lead to the apoptosis of mammalian cells. ${ }^{38}$ Bao et al. ${ }^{39}$ successfully fabricated GO nanosheets, which were impregnated with silver nanoparticles (Ag NPs) via the in situ reduction of adsorbed $\mathrm{Ag}^{+}$by hydroquinone (HQ) in a citrate buffer solution. The Ag NP/GO composites performed efficiently in decreasing the count of E. coli from $10^{6} \mathrm{CFU} \mathrm{mL}^{-1}$ to 0 with $45 \mathrm{mg} \mathrm{L}^{-1} \mathrm{GO}$ in water.

A possible mechanism proposed for the GO nanosheet mediated Ag deposition process is schematically illustrated in Fig. 10(a). The Ag NPs are homogeneously assembled on the micron scale GO (Fig. 10(b)). To check the antibacterial effect in

(a)

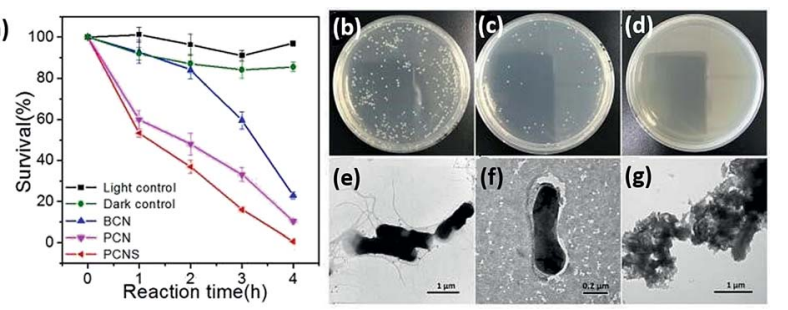

Fig. 9 (a) Visible-light-driven photocatalytic disinfection performance against $E$. coli between $\mathrm{BCN}, \mathrm{PCN}$, and PCNS. Images of $E$. coli colonies on solid culture medium (b) before irradiation and (c) after disinfection for $2 \mathrm{~h}$ and (d) for $4 \mathrm{~h}$ using PCNS. TEM images of $E$. coli cells $(e)$ before irradiation and $(f, g)$ after disinfection for $4 \mathrm{~h}$ using PCNS (this figure has been reproduced from ref. 34 with permission from American Chemical Society).
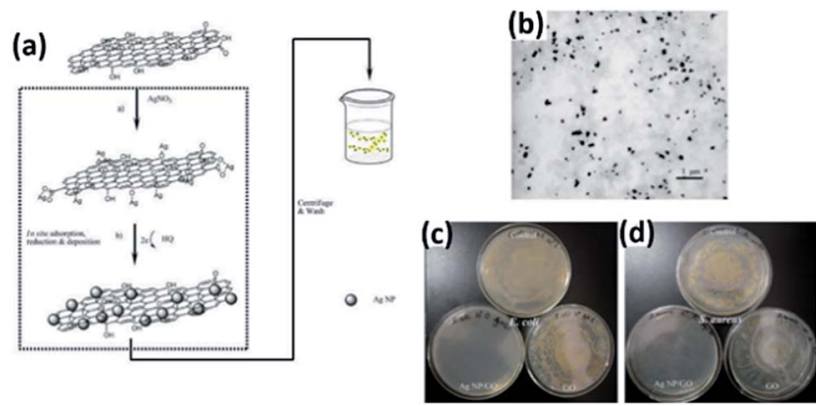

Fig. 10 (a) Proposed scheme for the fabrication of the Ag NP/GO composite suspension. (b) TEM image of Ag NP/GO composites. (c) Photographs of colonies of $E$. coli and (d) S. aureus cultivated on $\mathrm{MH}$ agar plates obtained from incubated suspensions with water (control), $\mathrm{GO}$ and $\mathrm{Ag} N \mathrm{~N} / \mathrm{GO}$ composites (this figure has been reproduced from ref. 39 with permission from Elsevier).

aquatic media, GO and composite suspensions were added into bacteria-containing water, respectively. In Fig. 10(c and d), as to the GO samples, no obvious antibacterial effect was observed, whereas the bacteria cells of $E$. coli or $S$. aureus were reduced greatly in the presence of the composites.

More importantly, as a common medical reagent, $\mathrm{H}_{2} \mathrm{O}_{2}$ is widely used in wound disinfection to avoid bacterial infection. Nevertheless, the disinfection ability of $\mathrm{H}_{2} \mathrm{O}_{2}$ is lower than that of hydroxyl radicals, so a high concentration of $\mathrm{H}_{2} \mathrm{O}_{2}$ is needed to solve this problem. ${ }^{40}$ Graphene quantum dots (GQDs) are defined as a kind of 0D material, and possess characteristics derived from both graphene and carbon dots (CDs). ${ }^{41}$ Simultaneously, GQDs display a higher peroxidase-like activity than graphene due to their excellent electron transportation properties. $^{\mathbf{4 2 , 4 3}}$ Sun et $a .^{\mathbf{4 4}}$ reported an antibacterial system combining the "safe" carbon based nanomaterials of GQDS with a low level of $\mathrm{H}_{2} \mathrm{O}_{2}$. All the experimental data in vitro showed that this intrinsic activity realized a high enhancement of the antibacterial activity of $\mathrm{H}_{2} \mathrm{O}_{2}$, and the particular system

(a)

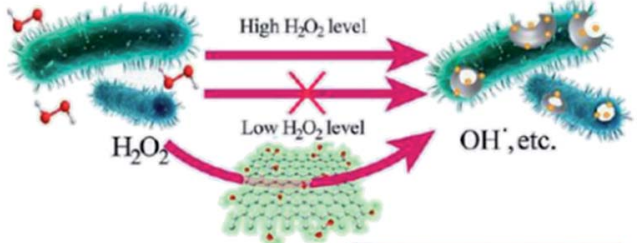

(b)

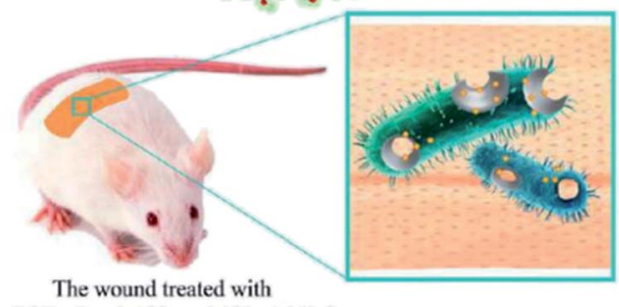

GQDs-Band-Aids and $100 \mu \mathrm{M} \mathrm{H} \mathrm{H}_{2}$

Fig. 11 (a) The system based on GQDs and low levels of $\mathrm{H}_{2} \mathrm{O}_{2}$ for antibacterial applications. (b) The GQD Band-Aids used in wound disinfection in vivo (this figure has been reproduced from ref. 44 with permission from American Chemical Society). 
Table 1 Comparison of various photocatalysts for disinfection

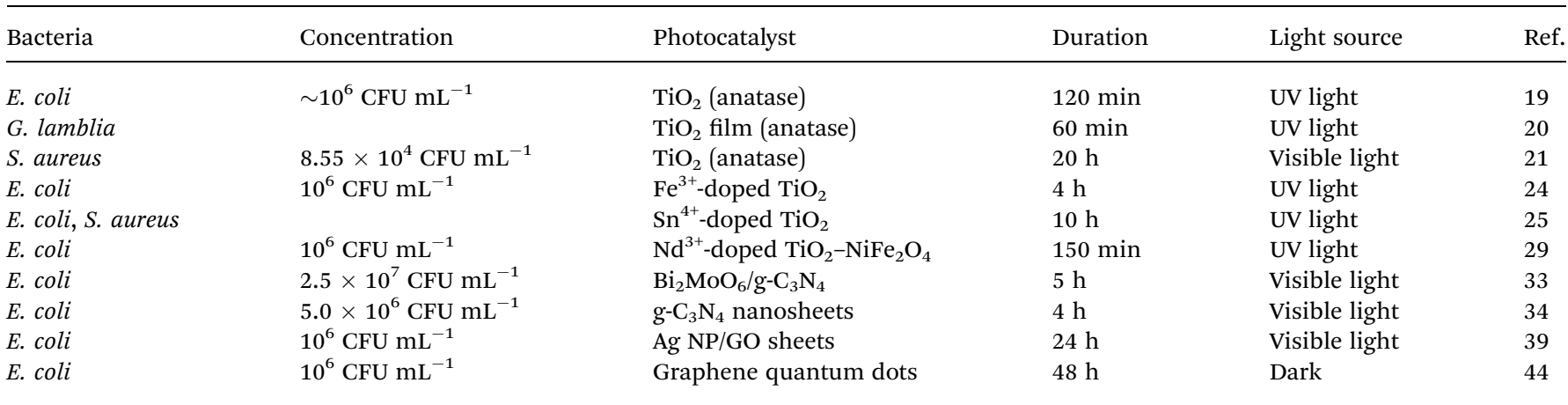

exhibited broad application of antibacterial activity against not only Gram-negative (Escherichia coli) but also Gram-positive (Staphylococcus aureus) bacteria. Fig. 11(a) illustrates a more detailed mechanism. In the presence of GQDs, $\mathrm{H}_{2} \mathrm{O}_{2}$ could be converted into hydroxyl radicals (high antibacterial activity), thus improving the antibacterial performance of $\mathrm{H}_{2} \mathrm{O}_{2}$, which made it possible to save the cost of a high concentration of $\mathrm{H}_{2} \mathrm{O}_{2}$ in wound disinfection. What's more, GQD-Band-Aids were prepared and used in wound disinfection in vivo (seen from Fig. 11(b)).

In this section, we have reviewed novel carbon materials, such as $\mathrm{g}-\mathrm{C}_{3} \mathrm{~N}_{4}$ nanosheets, GO nanosheets and graphene quantum dots in photocatalytic sterilization. It is expected that some other carbon materials and 2D transition metal materials may act as alternative candidates in this field as well.

Table 1 summarizes the ability of different photocatalysts for the inactivation of bacteria including Gram-positive and Gramnegative bacteria. It is revealed that $\mathrm{TiO}_{2}$ nanomaterials need less time to achieve high efficiency under UV light. After the $\mathrm{TiO}_{2}$ materials were modified such as doping with metal ions, the disinfection ability can be extended to visible light region. In comparison with $\mathrm{TiO}_{2}$, the $\mathrm{C}_{3} \mathrm{~N}_{4}$ based nanomaterials could work for disinfection under visible light irradiation. When the $\mathrm{Ag}$ nanoparticles were loaded onto GO sheets or GQDs, it can also realize visible light driven disinfection, however, it always needs a long reaction time. Even so, it is much better than the disinfection efficiency of graphene based nanomaterials (i.e. graphene quantum dots) in the dark. Therefore, $\mathrm{TiO}_{2}$ is still an ideal UV-driven photocatalyst for the inactivation of bacteria, while $\mathrm{C}_{3} \mathrm{~N}_{4}$ is a potential candidate for visible light-driven disinfection. In order to improve the efficiency of photocatalytic disinfection (or sterilization), composite modification of a variety of catalysts will be the focus of research.

\section{Conclusions and outlook}

In summary, since the discovery of the application of $\mathrm{TiO}_{2}$ in photocatalytic sterilization, scientists around the world have made many efforts to develop huge amounts of nanomaterials, which are commonly operated under visible light or UV light irradiation for photocatalytic sterilization. Commonly, the most widely used photocatalyst is still $\mathrm{TiO}_{2}$. In addition, after several years of development, some novel carbon based photocatalytic nanomaterials emerged, such as $\mathrm{g}-\mathrm{C}_{3} \mathrm{~N}_{4}$, carbon materials and graphene. These materials can act as independent materials or excellent supporting materials in disinfection. In combination with the present trend, $2 \mathrm{D}$ transition metal materials may possess similar or more excellent ability in photocatalytic sterilization, owing to the large surface area and excellent utilization of light. Although photocatalytic sterilization has made great progress in recent years, one of the main obstacles to bringing photocatalytic water disinfection into practical application is photocatalyst recycling and photocatalytic reactor design. This is because most of the synthesized photocatalysts are in powder form, which is difficult to be reunited and recycled in industry. Additionally, the light utilization of semiconductor photocatalysts in water is very limited, leading to low efficiency of disinfection rate. All of these problems greatly limit the possibility of practical application of photocatalytic sterilization in the future. Regarding this, future research direction may focus on the synthesis of photocatalytic membranes, magnetic photocatalysts and threedimensional catalysts that can be easily recycled. Moreover, it is imperative to develop other coupling techniques with the photocatalytic method, such as Advanced Oxidation Processes (AOPs), including Fenton, Fenton-like and photo-Fenton processes and peroxymonosulfate (PMS) activation etc. Therefore, improving the dispersion of the semiconductor photocatalysts in water and the utilization of light, and the development of the coupling techniques based on the combination of photocatalysis and other sterilization technologies such as adsorption or AOPs are major research areas that need to be further investigated.

\section{Conflicts of interest}

There are no conflicts to declare.

\section{Acknowledgements}

This work has been supported by the State Key Research Development Program of China (No. 2016YFA0204200), National Nature Science Foundation of China (No. 81401466, 21822603, 81501521). 


\section{Notes and references}

1 W. Raza, S. M. Faisal, M. Owais, D. Bahnemann and M. Muneer, RSC Adv., 2016, 6, 78335-78350.

2 V. Shanmugam and K. S. Jeyaperumal, Appl. Surf. Sci., 2018, 449, 617-630.

3 S. Sepahvand and S. Farhadi, RSC Adv., 2018, 8, 1012410140.

4 A. U. Rahman, A. U. Khan, Q. Yuan, Y. Wei, A. Ahmad, S. Ullah, Z. U. H. Khan, S. Shams, M. Tariq and W. Ahmad, J. Photochem. Photobiol., B, 2019, 193, 31-38.

5 G. R. S. Andrade, C. C. Nascimento, Z. M. Lima, E. TeixeiraNeto, L. P. Costa and I. F. Gimenez, Appl. Surf. Sci., 2017, 399, 573-582.

6 J. Liu, Y. Wang, J. Ma, Y. Peng and A. Wang, J. Alloys Compd., 2019, 783, 898-918.

7 K. Qi, B. Cheng, J. Yu and W. Ho, J. Alloys Compd., 2017, 727, 792-820.

8 L. Midya, A. S. Patra, C. Banerjee, A. B. Panda and S. Pal, J. Hazard. Mater., 2019, 369, 398-407.

9 B. Najma, A. K. Kasi, J. Khan Kasi, A. Akbar, S. M. A. Bokhari and I. R. C. Stroe, Appl. Surf. Sci., 2018, 448, 104-114.

10 V. Shanmugam and K. S. Jeyaperumal, Appl. Surf. Sci., 2018, 449, 617-630.

11 X. Zeng, Y. Wan, X. Gong and Z. Xu, RSC Adv., 2017, 7, 3626936278.

12 N. Serpone, Res. Chem. Intermed., 1994, 20, 953-992.

13 U. Stafford, K. A. Gray and P. V. Kamat, Res. Chem. Intermed., 1997, 23, 355-388.

14 Y. G. Shul, H. J. Kim, S. J. Haam and H. S. Han, Res. Chem. Intermed., 2003, 29, 849-859.

15 A. Fujishima, Nature, 1972, 238, 37-38.

16 J. H. Carey, J. Lawrence and H. M. Tosine, Bull. Environ. Contam. Toxicol., 1976, 16, 697-701.

17 T. Matsunaga, R. Tomoda, T. Nakajima and H. Wake, FEMS Microbiol. Lett., 1985, 29, 211-214.

18 J. C. Ireland, P. Klostermann, E. W. Rice and R. M. Clark, Appl. Environ. Microbiol., 1993, 59, 1668-1670.

19 C. Wei, W. Y. Lin, Z. Zainal, N. E. Williams, K. Zhu, A. P. Kruzic, R. L. Smith and K. Rajeshwar, Environ. Sci. Technol., 1994, 28, 934-938.

20 J. H. Lee, M. Kang, S.-J. Choung, K. Ogino, S. Miyata, M.-S. Kim, J.-Y. Park and J.-B. Kim, Water Res., 2004, 38, 713-719.

21 X. Wang, H. Hu, Z. Yang, Y. Kong, B. Fei and J. H. Xin, Catal. Commun., 2015, 72, 81-85.

22 P. V. Laxma Reddy, B. Kavitha, P. A. Kumar Reddy and K.-H. Kim, Environ. Res., 2017, 154, 296-303.
23 P. A. K. Reddy, P. V. L. Reddy, E. Kwon, K.-H. Kim, T. Akter and S. Kalagara, Environ. Int., 2016, 91, 94-103.

24 C. C. Trapalis, P. Keivanidis, G. Kordas, M. Zaharescu, M. Crisan, A. Szatvanyi and M. Gartner, Thin Solid Films, 2003, 433, 186-190.

25 F. Sayılkan, M. Asiltürk, N. Kiraz, E. Burunkaya, E. Arpaç and H. Sayllkan, J. Hazard. Mater., 2009, 162, 1309-1316.

26 P. Wu, R. Xie, J. A. Imlay and J. K. Shang, Appl. Catal., B, 2009, 88, 576-581.

27 C. Karunakaran, G. Abiramasundari, P. Gomathisankar, G. Manikandan and V. Anandi, J. Colloid Interface Sci., 2010, 352, 68-74.

28 S. Rana, J. Rawat and R. D. K. Misra, Acta Biomater., 2005, 1, 691-703.

29 S. Rana, J. Rawat, M. M. Sorensson and R. D. K. Misra, Acta Biomater., 2006, 2, 421-432.

30 T. Nardi, S. Rtimi, C. Pulgarin and Y. Leterrier, RSC Adv., 2015, 5, 105416-105421.

31 W.-J. Ong, L.-L. Tan, Y. H. Ng, S.-T. Yong and S.-P. Chai, Chem. Rev., 2016, 116, 7159-7329.

32 Y. Tian, F. Zhou, S. Zhan, Y. Yang, Y. Liu and Q. He, J. Inorg. Organomet. Polym., 2017, 27, 353-362.

33 J. Li, Y. Yin, E. Liu, Y. Ma, J. Wan, J. Fan and X. Hu, J. Hazard. Mater., 2017, 321, 183-192.

34 J. Xu, Z. Wang and Y. Zhu, ACS Appl. Mater. Interfaces, 2017, 9, 27727-27735.

35 W. Hu, C. Peng, W. Luo, M. Lv, X. Li, D. Li, Q. Huang and C. Fan, ACS Nano, 2010, 4, 4317-4323.

36 D. B. Warheit, B. R. Laurence, K. L. Reed, D. H. Roach, G. A. M. Reynolds and T. R. Webb, Toxicol. Sci., 2004, 77, 117-125.

37 A. Magrez, S. Kasas, V. Salicio, N. Pasquier, J. W. Seo, M. Celio, S. Catsicas, B. Schwaller and L. Forró, Nano Lett., 2006, 6, 1121-1125.

38 A. M. Pinto, I. C. Gonçalves and F. D. Magalhães, Colloids Surf., B, 2013, 111, 188-202.

39 Q. Bao, D. Zhang and P. Qi, J. Colloid Interface Sci., 2011, 360, 463-470.

40 E. Hayashi, T. Mokudai, Y. Yamada, K. Nakamura, T. Kanno, K. Sasaki and Y. Niwano, J. Biosci. Bioeng., 2012, 114, 193197.

41 J. Shen, Y. Zhu, X. Yang and C. Li, Chem. Commun., 2012, 48, 3686-3699.

42 A.-X. Zheng, Z.-X. Cong, J.-R. Wang, J. Li, H.-H. Yang and G.-N. Chen, Biosens. Bioelectron., 2013, 49, 519-524.

43 Y. Zhang, C. Wu, X. Zhou, X. Wu, Y. Yang, H. Wu, S. Guo and J. Zhang, Nanoscale, 2013, 5, 1816-1819.

44 H. Sun, N. Gao, K. Dong, J. Ren and X. Qu, ACS Nano, 2014, 8, 6202-6210. 